International Journal of Engineering \& Technology, $7(4.9)(2018) 8-13$
International Journal of Engineering \& Technology
SPC
Website: www.sciencepubco.com/index.php/IJET
Research paper

\title{
The relationship between work-life balance and women leadership performance: The mediation effect of organizational culture
}

\author{
Duan Wei Hua ${ }^{1,2^{*}}$, Nik Hasnaa Nik Mahmood ${ }^{1}$, Wan Normeza Wan Zakaria ${ }^{1}$, Li Cun Lin $^{2}$, Xia Yang \\ ${ }^{1}$ Razak Faculty of Technology and Informatics, Universiti Teknologi Malaysia \\ ${ }^{2}$ RazManagement School, North Minzu University, China \\ ${ }^{3}$ Azman Hashim International Business School, Universiti Teknologi Malaysia \\ *Corresponding author E-mail: amandaduanutm@gmail.com
}

\begin{abstract}
The objective of this study is examining the relationship among work-life balance, organizational culture and women leadership performance in China, and testing the conceptual research model connecting those three variables. The model was designed and tested by Partial Least Square (PLS) based on data collected from a survey of 290 available questionnaires. The results confirmed that organizational culture has significant and positive mediating effect on the relationship between work-life balance and women leadership performance in China. The findings indicated that the good relationship between work-life balance and organizational culture would lead to a high women leadership. Therefore, organizational culture and work-life balance play crucial function within women leaders in China
\end{abstract}

Keywords: Organization Culture, Work-life Balance, Women Leadership Performance

\section{Introduction}

Since the Washington post appointed Katherine Graham as a chief executive officer (CEO) in 1972, the challenges women have faced in career development in leadership positions have become attention [1]. Within the past few years, the number of women in the paid labor market has a big change in the demographic, social and economic area around the world [2]. Women obtained more opportunities to rising up to the leading positions in work environment or even became heads of states and government in the world [3, 4]. Centre [5] commented on its website front page: great leaders know that being committed to the success of an organization means being committed to their own personal development.

There were several scholars pay attention on the study of women leaders and try to find out what are the main factors influencing the women leadership performance $[6,7,8,9,10]$. Cashman [11] pointed out that leaders with a good way of work-life balance can achieve more effective performance. The promptest way in which leaders and organizations can support work-life balance is by promoting and implementing work-life programs and familyfriendly policies $[12,13]$. In addition, a strong organization culture emphasizes healthy working conditions, effective communication, modern ideas and technology, rational rewards and incentives, quick complaints, effective leadership, and so on [14], and organizational culture played a very important role for both work-life balance and leadership performance $[15,16]$.

Thus, the aims of this study are to examine the mediation effect of organization culture on the relationship between work-life balance and women leadership performance and to test the conceptual research model connecting those three variables.

\section{Literature Review}

\subsection{Work life balance}

Gurvis and Patterson [17] defined work-life balance was the equally weighed time for an individual to experience his or her expectations of commitment to career, family, friends, community, and leisure pursuits. Work-life balance continues to grow as a priority of prospective employees and an expectation of those who comprise an organization's workforce. Then, Winkler [18] defined that work-life balance based on 8 elements including 'being on purpose,' 'health, hobbies and habits,' and 'relationships,' 'lightening up,' 'spirituality,' 'prioritizing,' 'good thinking' and 'values and commitments.' In the context of this study, work-life balance was measured based on Winkler's 8 traits of work-life balance [18].

\subsection{Organizational culture}

Trice and Beyer [19] contended that 'organizational culture, like other cultures, develop as groups of people struggle to make sense of and cope with their worlds (p.4)' . Schein [20] argued that organizational culture as 'the accumulated shared learning of a given group, covering behavioral, emotional, and cognitive elements of the group members' total psychological functioning (p.17)'. Simply presented, organizational culture is "the way things are done around here, as well the way things are understood, judged, and valued. (p 112)" [21]. Flamholtz and Randle [22] believed that organizational culture could be regarded as "corporate personality" and can be defined as a combination of 
values, beliefs, and norms that affect the behavior of people who are members of an organization. In the context of this study, the organizational culture was measured based on Denison and Mishra 's four traits of organizational cultures, including involvement, consistency, adaptability, and mission [23].

\subsection{Women leadership performance}

Dulewicz and Higgs [24] believed that leadership performance is the basis for people to work together in a team and was considered as the most important aspect of human behavior research. The performance of leadership is a way to manage and adjust leadership behaviors, strategies and outcomes, including the three important elements, which are the realization of organizational, team and individual performance [25]. Some of the characteristics of leadership are measuring the success or failure of a project, such as "motivating others, managing resources, delegating and developing". In the context of this study, leadership performance is measured based on five factors, namely, building relationship, engaging talent, delivering results, creating the future, and personal leadership [26]

\subsection{Relationship between work-life balance and women leadership performance}

Many researchers are studying the relationship between work-life balance and women leadership performance. Courtney [27] used a qualitative narrative survey method to interview six mothers with higher education leadership status, finding that the work-life balance may be complex, and it will make women face the dilemma of management leadership role and birth of children, which will affect the performance of female leadership. Mangels [28] gathered data from a survey of 247 female and male college presidents and interviewed 12 female presidents who graduated from U.S. colleges and universities. The results showed that worklife balance and leadership success are linked, harmony/accord work-life balance was found to be significantly positively correlated with the President's success. The President's life is considered to be the most important predictor of his/her success. Heath [29] collected data from interviewing 22 women leaders to determine strategies for integrating balance into personal and professional life. The findings suggested that women are more likely to succeed in multiple roles if their careers are meaningful and fulfilling by keeping a work-life balance.

In view of that, we hypothesize: H1: There is a positive relationship between work-life balance and women leadership performance

\subsection{Relationship between work-life balance and organizational culture}

The study of the relationship between work-life balance and organizational culture has attracted several scholars. Kottabi [30] found in the federal government to support work/life balance, there were six topics related to the role of leadership, which were (a) leadership to support work/life balance, (b) flexibility, (c) a formal training, (d) mission to fulfill, (e)trust, (f) leadership style. In addition, these themes support and enable employees to achieve organizational goals and work-life balance simultaneously in the federal government, which can help employees achieve a better life balance. Jones, Burke [31] conducted a secondary analysis of attitude survey data from a large professional services company. During the survey, the company had about 2,150 employees and received 1,608 samples. It is believed that 'organizational culture is the key to success of work and life integration (p.235). If the organizational culture supports the integration of work and life, the increase in personal control will be effective. Bond [32] believed that organizational culture was significantly associated with work-life balance, which suggests that without a supportive organizational culture, the arrangement provided in themselves may not necessarily lead to a better work-life balance.

In view of that, we hypothesize $\mathrm{H} 2$ : There is a positive relationship between work-life balance and organizational culture.

\subsection{Relationship between organizational culture and women leadership performance}

Some scholars are focusing on studying the relationship between organizational culture and women leadership performance. Meng [33] believed that the test of non-recursive structure model confirmed that organizational culture had a direct and positive impact on the achievements of excellent leaders in public relations. More notably, excellent leadership in public relations can also influence the organizational culture, by reshaping it to support public relations efforts in the organization. Lucas [34] conducted a study to determine whether transformational leadership behavior predicted constructive organizational culture in manufacturing enterprises. The results showed that transformational leadership style/performance is predictive and positively correlated with constructive organizational culture. Mishra [35] argued that organizational culture helps to build a strong value system and work ethic among employees, which is directly related to productivity. A strong culture emphasizes healthy working conditions, effective communication, modern concepts and techniques, rational rewards and incentives, quick complaints, effective leadership, and so on.

In view of that, we hypothesize: $\mathrm{H} 3$ : There is a positive relationship between organizational culture and women leadership performance

\subsection{The mediation role of organizational culture in the relationship between work-life balance and women leadership performance}

Many studies have found that organizational culture plays a mediating role in work-life balance and leadership performance. Berson, Oreg [15] found that entrepreneurial cultures mediated the relationship between work-life balance and company sales growth of CEOs. Cegarra-Leiva, Sánchez-Vidal [36], in their study on 229 SMEs representing the metal industry sector of Southeast Spain have found an organizational culture (WLB supportive culture) mediates the effect of the availability of WLB practices on organizational and leadership performance. Munn (16) in his study of data from the 2008 National Study of the Changing Workforce (NSCW study) demonstrated that mediating role of organizational culture on the work-life benefits with financial and leadership performance.

In view of that, we hypothesize: H4: Organizational culture mediates the relationship between work-life balance and women leadership performance.

\section{Research method}

\subsection{Research instrument}

This study adopted and adapted instruments to measure work-life balance, organizational culture and women leadership performance based on "Work-life Balance Instrument" designed by Winkler [18]; 'Organizational Culture Instrument' designed by Denison (37) and 'Leadership Performance Instrument' based on PerformNuace [26], Key Associates [38] and Nixon, Harrington 
[39]. A five-point Likert scale was utilized from strongly disagree $\backslash$ not at all successful to strongly agree $\backslash$ very successful.

\subsection{Population and sample method}

In this study, the unit of analysis was the individual of the women leaders from the private and public sector in Ning Xia Autonomous Region of China.

\subsection{Data collection}

Firstly, a pilot survey of 30 women leaders from Ningxia was conducted. The pilot study's data was used to assess the reliability of the multiple-item measurement scales used in the questionnaire by employing Cronbach's alpha [40]. The range of Cronbach's Alpha from 0.816-0.855, which indicated the satisfactory reliability of the measures and implied that all the measurement scales were good enough to be used for the actual data collection phase [41].

Secondly, a questionnaire was distributed among the target group Because we cannot get the total number of female leaders in Ning Xia, an un-probabilistic approach was employed [41]. 290 valid questionnaires were received from 320distributed questionnaires, with a response rate of $90.6 \%$. Thirdly, the outlier was tested by Mahalanobis distance (MD) in reference of Chi-square, the critical value at the level of significance of 0.001 and 4 degrees of freedom was at 18.467 [42]. In this study, there was only one case (at 18.798) was identified as outlier which MD was higher than 18.467. It seemed that the outlier was not a big threat to this study and can be ruled out.

\subsection{Reliability and validation: elaborate on the content of instrument}

The partial least squares (PLS) technique was adopted to do the empirical test of the research model. The measurement model and structure model were evaluated by using Smart PLS 3.0 software [43], because it can evaluate all the paths at the same time [44, 45] without requiring large sample size [45]. Figure 1 described the model with all the potential constructs (shaded areas) and measurement items (rectangles).

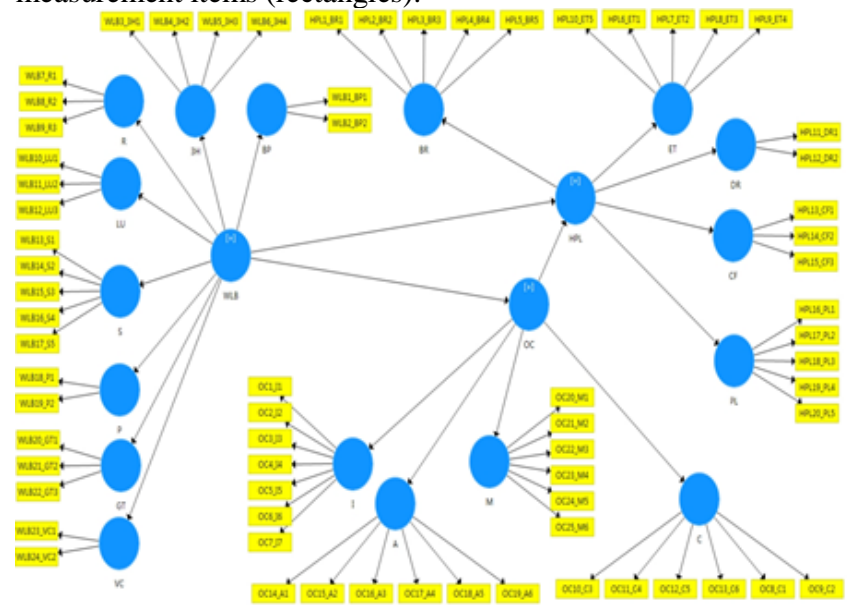

Fig. 1: Measurement Model Used for Confirmatory Factor Analysis (CFA)

Note1: WLB=Work-life Balance, $\mathrm{BP}=\mathrm{Being}$ on Purpose, $3 \mathrm{H}=\mathrm{Health}$, Hobbies, and Habits R=Relationship, LU=Lightening Up, S=Spirituality,

$\mathrm{P}=$ Prioritizing, $\mathrm{GT}=\mathrm{Good}$ Thinking, $\mathrm{VC}=$ Values and Commitments. $\mathrm{OC}=$ Organizational Culture, $\mathrm{I}=$ Involvement, $\mathrm{C}=$ Consistency,

$\mathrm{A}=$ Adaptability, $\mathrm{M}=$ Mission.

$\mathrm{BR}=$ Building Relationship, ET=Engaging Talent, DR=Delivering Results, $\mathrm{CF}=$ Creating the Future, $\mathrm{PL}=$ Personal Leadership

Note 2: Hereinafter Inclusive.
Table 1: Assessment of Items Reliability (Number $=69: \mathrm{WLB}=24, \mathrm{OC}=25$, $\mathrm{WLP}=20$ )

\begin{tabular}{|c|c|c|c|c|c|}
\hline $\begin{array}{l}\text { Items of } \\
\text { WLB }\end{array}$ & $\begin{array}{c}\text { Load- } \\
\text { ing }\end{array}$ & $\begin{array}{c}\text { Items of } \\
\text { OC }\end{array}$ & $\begin{array}{c}\text { Load- } \\
\text { ing }\end{array}$ & $\begin{array}{c}\text { Items of } \\
\text { WLP }\end{array}$ & $\begin{array}{c}\text { Load- } \\
\text { ing }\end{array}$ \\
\hline WLB1_BP1 & 0.959 & OC1_I1 & 0.860 & $\begin{array}{c}\text { WLP1_BR } \\
1 \\
\end{array}$ & 0.868 \\
\hline WLB2_BP2 & 0.953 & OC2_I2 & 0.579 & $\begin{array}{c}\text { WLP2_BR } \\
2\end{array}$ & 0.922 \\
\hline WLB3_3H1 & 0.677 & OC3_I3 & 0.861 & $\begin{array}{c}\text { WLP3_BR } \\
3\end{array}$ & 0.638 \\
\hline WLB4_3H2 & 0.888 & OC4_I4 & 0.635 & $\begin{array}{c}\text { WLP4_BR } \\
4\end{array}$ & 0.886 \\
\hline WLB5_3H3 & 0.896 & OC5_I5 & 0.712 & $\begin{array}{c}\text { WLP5_BR } \\
5\end{array}$ & 0.788 \\
\hline WLB6_3H4 & 0.593 & OC6_I6 & 0.638 & WLP6_ET1 & 0.857 \\
\hline WLB7_R1 & 0.895 & OC7_I7 & 0.888 & WLP7_ET2 & 0.905 \\
\hline WLB8_R2 & 0.917 & OC8_C1 & 0.831 & WLP8_ET3 & 0.796 \\
\hline WLB9_R3 & 0.662 & OC9_C2 & 0.806 & WLP9_ET4 & 0.827 \\
\hline $\begin{array}{c}\text { WLB10_L } \\
\text { U1 }\end{array}$ & 0.771 & $\begin{array}{c}\text { OC10_C } \\
3\end{array}$ & 0.884 & $\begin{array}{c}\text { WLP10_ET } \\
5\end{array}$ & 0.846 \\
\hline $\begin{array}{c}\text { WLB11_L } \\
\text { U2 }\end{array}$ & 0.947 & $\underset{4}{\mathrm{OC} 11 \_\mathrm{C}}$ & 0.542 & $\begin{array}{c}\text { WLP11_D } \\
\text { R1 }\end{array}$ & 0.734 \\
\hline $\begin{array}{c}\text { WLB12_L } \\
\text { U3 }\end{array}$ & 0.929 & $\begin{array}{c}\mathrm{OC} 12 \_\mathrm{C} \\
5\end{array}$ & 0.818 & $\begin{array}{c}\text { WLP12_D } \\
\text { R2 }\end{array}$ & 0.874 \\
\hline WLB13_S1 & 0.909 & $\begin{array}{c}\text { OC13_C } \\
6\end{array}$ & 0.728 & $\begin{array}{c}\text { WLP13_CF } \\
1\end{array}$ & 0.736 \\
\hline WLB14_S2 & 0.897 & $\begin{array}{c}\text { OC14_A } \\
1\end{array}$ & 0.703 & $\begin{array}{c}\text { WLP14_CF } \\
2\end{array}$ & 0.891 \\
\hline WLB15_S3 & 0.593 & $\begin{array}{c}\mathrm{OC} 15 \_\mathrm{A} \\
2\end{array}$ & 0.875 & $\begin{array}{c}\text { WLP15_CF } \\
3 \\
\end{array}$ & 0.919 \\
\hline WLB16_S4 & 0.908 & $\begin{array}{c}\text { OC16_A } \\
3\end{array}$ & 0.668 & $\begin{array}{c}\text { WLP16_PL } \\
1\end{array}$ & 0.601 \\
\hline WLB17_S5 & 0.886 & $\begin{array}{c}\text { OC17_A } \\
4\end{array}$ & 0.867 & $\begin{array}{c}\text { WLP17_PL } \\
2\end{array}$ & 0.824 \\
\hline WLB18_P1 & 0.945 & $\begin{array}{c}\text { OC18_A } \\
5\end{array}$ & 0.867 & $\begin{array}{c}\text { WLP18_PL } \\
3\end{array}$ & 0.581 \\
\hline WLB19_P2 & 0.626 & $\begin{array}{c}\text { OC19_A } \\
6\end{array}$ & 0.705 & $\begin{array}{c}\text { WLP19_PL } \\
4\end{array}$ & 0.694 \\
\hline $\begin{array}{c}\text { WLB20_G } \\
\text { T1 }\end{array}$ & 0.950 & $\begin{array}{c}\text { OC20_M } \\
1\end{array}$ & 0.879 & $\begin{array}{c}\text { WLP20_PL } \\
5\end{array}$ & 0.675 \\
\hline $\begin{array}{c}\text { WLB21_G } \\
\text { T2 }\end{array}$ & 0.539 & $\begin{array}{c}\text { OC21_M } \\
2\end{array}$ & 0.881 & & \\
\hline $\begin{array}{c}\text { WLB22_G } \\
\text { T3 }\end{array}$ & 0.957 & $\begin{array}{c}\text { OC22_M } \\
3\end{array}$ & 0.886 & & \\
\hline $\begin{array}{c}\text { WLB23_V } \\
\text { C1 }\end{array}$ & 0.756 & $\begin{array}{c}\text { OC23_M } \\
4\end{array}$ & 0.848 & & \\
\hline \multirow[t]{2}{*}{$\begin{array}{c}\text { WLB24_V } \\
\text { C2 }\end{array}$} & 0.929 & $\begin{array}{c}\text { OC24_M } \\
5\end{array}$ & 0.708 & & \\
\hline & & $\begin{array}{c}\text { OC25_M } \\
6\end{array}$ & 0.723 & & \\
\hline
\end{tabular}

\section{Results}

\subsection{Measurement model}

Reliability and validity are two core criteria of evaluation measurement [46]. In this study, the reliability and validity of this study were evaluated by using indicator reliability, convergent and discriminant validity. First is to test the indicator reliability. After the model was successfully constructed in smart PLS 3.0 (see Figure 1), the basic statistics information was estimated by running a PLS-SEM algorithm, with the threshold of loading speed at 0.70 $[47,48]$. Then, 16 items (Red figures) from total 69 loadings are lower than 0.70 and should be removed. Therefore, the 53 left items demonstrated satisfactory indicator reliability in this study (See Table 1).

Secondly, to evaluate the convergent validity, average variance extracted (AVE) and composite reliability (CR) were recommended by researchers $[49,50]$. According to Chin and Newsted [51], the AVE should above 0.50 , which means that over 50 percent of the variation in a particular construct is explained by the specified index. In addition, the CR should be greater than 0.70 to show a good indicator of internal consistency [52] . The average vari- 
ance extracted (AVE) and composite reliability (CR) shown in Table 2 were considered to meet these requirements mentioned above.

Table 2: Convergent Validity of Constructs on AVE and CR

\begin{tabular}{|l|l|l|}
\hline Constructs & $\begin{array}{l}\text { Average Variance } \\
\text { Extracted (AVE) }\end{array}$ & $\begin{array}{l}\text { Composite } \\
\text { bility (CR) }\end{array}$ \\
\hline Work-life Balance & 0.679 & 0.974 \\
\hline Organizational Culture & 0.562 & 0.962 \\
\hline $\begin{array}{l}\text { High-Performance Lead- } \\
\text { ership }\end{array}$ & 0.568 & 0.951 \\
\hline Note: $A V E>0.50(51) ; C R>0.70(52)$ & \\
\hline
\end{tabular}

Thirdly, The discriminant validity was used to distinguish the measurement between a construct [53] , and was determined via correlation matrix construction (see Table 3 ) and cross-loading (see Table 4) $[47,49]$. In Table 3, it was clear that the square root of the AVE (the bold number on the diagonal) is higher than the off-diagonal element in the columns and rows. Table 4 demonstrated the cross-loadings output of each block has a higher loading than other blocks in the same rows, which means that the discriminant validity was satisfied in this study.

Table 3: Inter-correlation Matrix Constructs

\begin{tabular}{|l|l|l|l|}
\hline Constructs & WLP & OC & WLB \\
\hline $\begin{array}{l}\text { High-Performance } \\
\text { Leadership }\end{array}$ & $\mathbf{0 . 9 5 3}$ & & \\
\hline $\begin{array}{l}\text { Organizational Cul- } \\
\text { ture }\end{array}$ & 0.856 & $\mathbf{0 . 9 5 0}$ & \\
\hline Work-life Balance & 0.768 & 0.828 & $\mathbf{0 . 9 2 4}$ \\
\hline
\end{tabular}

\subsection{Structural model}

The structural model of this study was assessed by the bootstrapping with 5,000 bootstrap samples in PLS [45]. And the relationship between the hypotheses of the study evaluated by the path coefficient ( $\beta$ ) [54] . In addition, there have two different models based on the Four-Step Technique mentioned by Baron and Kenny [55] to evaluate the mediation effect in this study, as shown in Table 5 below.

Table 5: Two Different Models Based on the Four-Step Technique

\begin{tabular}{|l|l|}
\hline Model Type & Content \\
\hline \multirow{4}{*}{$\begin{array}{l}\text { The Fodel } \\
\text { Mirst }\end{array}$} & $\begin{array}{l}\text { 1) A direct path from work-life balance to organizational } \\
\text { culture. }\end{array}$ \\
\cline { 2 - 3 } $\begin{array}{l}\text { 2) A direct path from work-life balance to women lead- } \\
\text { ership performance. }\end{array}$ \\
\cline { 2 - 3 } $\begin{array}{l}\text { 3) A direct path from organizational culture to women } \\
\text { leadership performance. }\end{array}$ \\
\hline Model Second & $\begin{array}{l}\text { 4) A direct path from work-life balance to women lead- } \\
\text { ership performance, and an indirect path from work-life } \\
\text { balance to organizational culture and then an } \\
\text { organizational culture to women leadership performance. }\end{array}$ \\
\hline
\end{tabular}

First of all, the first model was demonstrated with a direct path from work-life balance to organizational culture, work-life balance to women leadership performance and organizational culture to women leadership performance. With using PLS-SEM bootstrapping for 5,000 resamples with 5 percent significance, Table 6 demonstrated that each link was significant with t-value above 1.96 and p-value at 0.000 level, and the path coefficient $(\beta)$ of $0.782,0.795$, and 0.837 respectively without any indirect effect in it. Therefore, Hypotheses 1, 2, and 3 were confirmed.

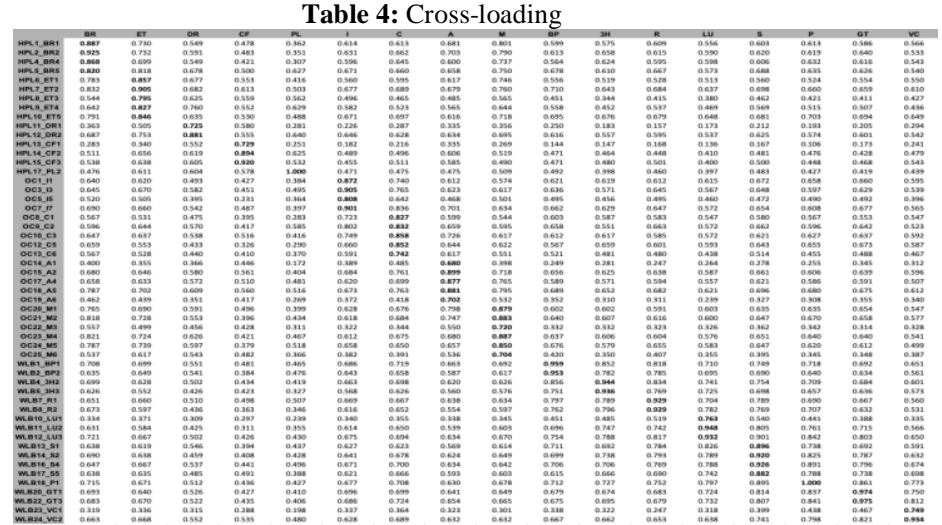

Note: The figures in boldface are the cross-loading of each construct.

Table 6: Direct Path Coefficient ( $\boldsymbol{\beta})$

\begin{tabular}{|l|l|l|l|}
\hline Direct & $\boldsymbol{\beta}$ & t-value & p-value \\
\hline WLB $\rightarrow$ WLP & 0.782 & 21.276 & 0.000 \\
\hline WLB $\rightarrow$ OC & 0.795 & 22.269 & 0.000 \\
\hline OC $\rightarrow$ WLP & 0.837 & 25.976 & 0.000 \\
\hline
\end{tabular}

Notes: $\beta>0.1 \&$ \&-values $>1.65 *(p<0.10) ; t$-values $>1.96 * *(p<0.05) ; t$ values $>2.58 * * *(p<0.01)(52)$

On the other hand, the second model was presented with organizational culture plays a mediation role in work-life balance and women leadership performance. According to Osman and Sentosa [56], when the indirect path through the mediation variance is established lead to the decrease of direct path coefficient $(\beta)$ between the independent variable and the dependent variable, indicating that the mediation effect is significant. In this study, SPSS PROCESS 3.0 by Hayes [57] was adopted to measure the mediation effect. Table 7 demonstrated after the organizational culture as a mediator, the direct coefficient $(\beta)$ had changed from 0.782 to 0.260 , indicating that the mediation effect is significant.

Meanwhile, according to Hair Jr, Hult [58], for the mediation assumption, the $t$-value should have significantly $(t>1.96$, twotailed, $\mathrm{p}<0.05$ ), and the confidence interval (CI) should exclude zero $(0)$ between the lower limit and upper limit values. In this study, PLS-SEM bootstrapping with resamples at 5\% significance level and 95\% confidence interval was adopted. Table 7 demonstrated that organizational culture mediates the relationship between work-life balance to women leadership performance, since t-value was higher than 1.96, and 95\% CI excluded zero (0). Therefore, hypothesis 4 was confirmed.

Table 7: The Result of SPSS PROCESS 3.0 ( $\boldsymbol{\beta}$ ) and PLS-SEM for Mediation Analysis

\begin{tabular}{|l|l|l|l|l|}
\hline Path & $\boldsymbol{\beta}$ & p-value & t-value & $\begin{array}{l}\text { 95\% Bootstrap- } \\
\text { ping Confidence } \\
\text { Interval }\end{array}$ \\
\hline $\begin{array}{l}\text { WLB } \rightarrow \text { OC } \rightarrow \\
\text { WLP }\end{array}$ & 0.260 & 0.000 & 10.893 & $(0.401,0.579)$ \\
\hline
\end{tabular}

\section{Discussion}

This study aims to a deep understanding of the mediation effect of organizational culture on the relationship between work-life balance and women leadership performance in China, and to build probable causal relationship among those three variables. In theory, the advantages of any model are hard to prove, so the empirical test is carried out [56]. In view of this, SPSS PROCESS 2.0 and PLS-SEM were adopted to analyze the gathered data, which indicates that all the 4 hypotheses were confirmed. Therefore, this study confirmed previous studies on the relationship study between work-life balance to women leadership performance, worklife balance to organizational culture, and organizational culture to women leadership performance [14, 27, 28, 30, 33, 59]. In addition, the results revealed that the organizational culture mediates the relationship between work-life balance and women leadership performance, which confirming the importance that scholars have 
always called to attach importance to the construction of organizational culture [16].

\section{Conclusion}

The study findings suggested that organizational culture among Chinese women leader can be enhanced by work-life balance improvement. On the other hand, women leadership performance can be strengthened and enhanced by raising the level of organizational culture among women leaders. Thirdly, the findings implied that the good relationship between work-life balance and organizational culture would lead to a high women leadership. Therefore, organizational culture and work-life balance play a crucial function within women leaders in China. Finally, it is worth noting that this study only obtained survey data from a province in northwest China and its universality and representativeness remains to be discussed.

\section{References}

[1] CATALYST (2017). Women On Corporate Boards Globally.

[2] Programme UND (2007), Human Development report 2007/2008 Fighting climate change: human solidarity in a divided world. New York, USA: Palgrave Macmillan.

[3] Benson J \& Yukongdi V (2005), Asian women managers: participation, barriers and future prospects. Asia Pacific Business Review 11(2):283-91.

[4] Dolan J \& Deckman MM (2017), Swers ML. Women and politics: Paths to power and political influence: Rowman \& Littlefield.

[5] Centre BV (2018), Leadership \& Performance.

[6] Spector PE, Cooper CL, Poelmans S, Allen TD, O'DRISCOLL M, Sanchez JI, et al (2004), A cross-national comparative study of work-family stressors, working hours, and well-being: China and Latin America versus the Anglo world. Personnel Psychology 57(1), 119-42.

[7] Schueller-Weidekamm C \& Kautzky-Willer A (2012), Challenges of work-life balance for women physicians/mothers working in leadership positions. Gender medicine 9(4), 244-50.

[8] Watts JH (2009), 'Allowed into a man's world'meanings of worklife balance: Perspectives of women civil engineers as 'minority'workers in construction. Gender, Work \& Organization 16(1), 37-57.

[9] Guillaume C \& Pochic S (2009), What would you sacrifice? Access to top management and the work-life balance. Gender, Work \& Organization 16(1), 14-36.

[10] Adame C, Caplliure E-M \& Miquel M-J (2016), Work-life balance and firms: A matter of women? Journal of Business Research 69(4), 1379-83.

[11] Cashman K (2008), Leadership from the Inside Out: Becoming a Leader for Life: Easyread Super Large 18pt Edition: ReadHowYouWant. com.

[12] Wang P \& Walumbwa FO (2007), Family-friendly programs, organizational commitment, and work withdrawal: the moderating role of transformational leadership. Personnel Psychology 60(2), 397-427.

[13] Lapierre LM \& Allen TD (2006), Work-supportive family, familysupportive supervision, use of organizational benefits, and problemfocused coping: implications for work-family conflict and employee well-being. Journal of occupational health psychology $11(2), 169$

[14] Mishra S (2009), A study of organisational culture with reference to productivity leadership and organisational effectiveness a study conducted in selected industrial organisations in Gujarat. Available from ProQuest Dissertations \& Theses Global (1782319875).

[15] Berson Y, Oreg S \& Dvir T, editors (2005), ORGANIZATIONAL CULTURE AS A MEDIATOR OF CEO VALUES AND ORGANIZATIONAL PERFORMANCE. Academy of Management Proceedings; Academy of Management Briarcliff Manor, NY 10510.

[16] Munn SL (2012), Developing a work-life system using types of organizational culture: An integrated perspective of individuals, organizations and policy: The Ohio State University.

[17] Gurvis J \& Patterson G (2005), Balancing act: Finding equilibrium between work and life. Leadership in Action 24(6), 4-9.
[18] Winkler JC (2010), Work-Life Balance: Strategies for Attaining and Maintaining Work-Life Balance: ERIC

[19] Trice HM \& Beyer JM (1993), The cultures of work organizations: Prentice-Hall, Inc.

[20] Schein EH (2004), Organizational Culture and Leadership (JosseyBass business \& management series): Jossey Bass Incorporated.

[21] Davies HT, Nutley SM \& Mannion R (2000), Organisational culture and quality of health care. BMJ Quality \& Safety 9(2), 1119.

[22] Flamholtz E \& Randle Y (2011), Corporate culture: The ultimate strategic asset. American: Stanford University Press.

[23] Denison DR \& Mishra AK (1995), Toward a theory of organizational culture and effectiveness. Organization science 6(2), 204-23.

[24] Dulewicz V \& Higgs M (2005). Assessing leadership styles and organisational context. journal of Managerial Psychology 20(2), $105-23$.

[25] Svennerstål ABP (2015), Performance Leadership A leadership performance tool created by Climber and Svennerstål \& Partners.

[26] PerformNuace (2010), Building High-Performance Leaders.

[27] Courtney NR (2014), Higher Education Leadership and Women: Understanding the Work-life Balance Through the Voices of Real Moms: University of Wyoming.

[28] Mangels SE (2008), Does balance matter? The relationship between work-life balance and success for women college presidents ProQuest.

[29] Heath K(2012), Women in leadership: Strategies for work-life balance: Pepperdine University.

[30] Kottabi D (2011), Exploring the leadership's role in supporting work-life balance in the federal government: UNIVERSITY OF PHOENIX.

[31] Jones F, Burke RJ \& Westman M (2013), Work-life balance: A psychological perspective: Psychology Press.

[32] Bond S (2004), Organisational culture and work-life conflict in the UK. International Journal of Sociology and Social Policy 24(12), $1-24$.

[33] Meng J (2014), Unpacking the relationship between organizational culture and excellent leadership in public relations: An empirical investigation. Journal of Communication Management 18(4), 36385.

[34] Lucas DB (2005), A study of the relationship between transformational leadership and constructive organizational culture in small manufacturing companies: ProQuest.

[35] Mishra S (2009), A study of organisational culture with reference to productivity leadership and organisational effectiveness a study conducted in selected industrial organisations in Gujarat.

[36] Cegarra-Leiva D, Sánchez-Vidal ME \& Gabriel Cegarra-Navarro J (2012), Understanding the link between work life balance practices and organisational outcomes in SMEs: The mediating effect of a supportive culture. Personnel Review 41(3), 359-79.

[37] Denison DR (1990), Corporate culture and organizational effectiveness: John Wiley \& Sons.

[38] Key Associates I (2017), High Performance Leadership Assessing Your Skills.

[39] Nixon P, Harrington M \& Parker D (2012), Leadership performance is significant to project success or failure: a critical analysis. International Journal of productivity and performance management 61(2), 204-16.

[40] Coopers PWH (2008), The Leaking Pipelines: Where are our female leaders? 79 women share their stories. Global Human Capital, Gender Advisory Council, retrieved May 2.

[41] Sekaran U \& Bougie R (2016), Research methods for business: A skill building approach: John Wiley \& Sons..

[42] Pallant J \& Manual SS (2010), A step by step guide to data analysis using SPSS. Berkshire UK: McGraw-Hill Education.

[43] Ringle CM, Wende S \& Becker J-M (2015), SmartPLS 3. Boenningstedt: SmartPLS GmbH

[44] Vinzi VE, Trinchera L \& Amato S (2010), PLS path modeling: from foundations to recent developments and open issues for model assessment and improvement. Handbook of partial least squares: Springer, 47-82.

[45] Gefen D, Straub D \& Boudreau M-C (2000), Structural equation modeling and regression: Guidelines for research practice. Communications of the association for information systems 4(1), 7.

[46] Kubiszyn T \& Borich G (2015), Educational testing and measurement: John Wiley \& Sons Incorporated; 2015. 
[47] Chin WW (1998), The partial least squares approach to structural equation modeling. Modern methods for business research 295(2), 295-336

[48] Hair Jr JF, Sarstedt M, Hopkins L, Kuppelwieser VG (2014), Partial least squares structural equation modeling (PLS-SEM) An emerging tool in business research. European Business Review $26(2), 106-21$

[49] Fornell C \& Larcker DFB (1981), Structural equation models with unobservable variables and measurement error: Algebra and statistics. Journal of marketing research 382-8.

[50] Hair JF, Black WC, Babin BJ \& Anderson RE (2010), Applications of SEM. Multivariate data analysis. Pearson, Upper Saddle River.

[51] Chin WW \& Newsted PR (1999) Structural equation modeling analysis with small samples using partial least squares. Statistical strategies for small sample research 1(1), 307-41.

[52] Hair JF, Ringle CM \& Sarstedt M (2011), PLS-SEM: Indeed a silver bullet. Journal of Marketing theory and Practice 19(2), 13952.

[53] Henseler J, Ringle CM \& Sarstedt M (2015), A new criterion for assessing discriminant validity in variance-based structural equation modeling. Journal of the academy of marketing science 43(1), 11535.

[54] Mohd Mustamil N (2010), The influence of culture and ethical ideology on ethical decision making process of Malaysian managers: Curtin University.

[55] Baron RM \& Kenny DA (1986), The moderator-mediator variable distinction in social psychological research: Conceptual, strategic, and statistical considerations. Journal of personality and social psychology 51(6), 1173.

[56] Osman Z \& Sentosa I (2013), Mediating effect of customer satisfaction on service quality and customer loyalty relationship in Malaysian rural tourism.

[57] Hayes AF (2012), PROCESS: A versatile computational tool for observed variable mediation, moderation, and conditional process modeling. University of Kansas, KS

[58] Hair Jr JF, Hult GTM, Ringle C \& Sarstedt M (2016), A primer on partial least squares structural equation modeling (PLS-SEM): Sage Publications.

[59] Clouston TJ (2012), The influence of organizational workplace cultures on employee work-life balance: Cardiff University. 